ORIGINAL ARTICLE

\title{
Description of Ascariasis in Children Aged 2 to 12 Years at the Martha Friska Hospital, Pulo Brayan, Medan
}

\author{
Said Munazar Rahmat ${ }^{1,2}$ \\ ${ }^{1}$ Masters of Tropical Medicine, Faculty of Medicine, Universitas Sumatera Utara \\ ${ }^{2}$ Department of Tropical Medicine, Faculty of Medicine, Universitas Muhammadiyah Sumatera Utara \\ Correspondence email: saidmunazarrahmat@yahoo.com
}

\begin{abstract}
Province of North Sumatera is one of the provinces with the most Ascariasis cases which affects children. This study aims to determine the description of ascariasis patients aged 212 years who are treated at the Martha Friska Pulo Brayan Hospital, Medan. This study is a descriptive study with a method cross-sectional, using consecutive sampling, which was conducted on patients who met the inclusion criteria from January to October 2017. The results of the study showed that most of the ascariasis subjects were male, pre-school age with good nutritional status, had normal $\mathrm{Hb}$ and Eosinophil levels.
\end{abstract}

Keywords: Ascariasis, pre-school age, nutritional status

\section{INTRODUCTION}

Contributors to the number of ascariasis in the world are tropical countries, especially Asia and Africa. In Southeast Asia, the incidence of ascariasis reaches 97 million people and Indonesia includes 60$69 \%$ of children aged 2-12 years, where North Sumatra is one of the provinces with the highest number of sufferers where 50$80 \%$ is suffered by school-age children. $1,2,3$ This study aims to determine the description of ascariasis patients aged 2-12 years who were treated at the Martha Friska Hospital Medan.

\section{METHODS}

This descriptive study used a crosssectional method, with consecutive sampling, located at the Martha Friska Hospital, Pulo Brayan Village, East Medan
District from January to October 2017. Ascariasis diagnostic enforcement used the Kato method, and the research subjects were children aged 2- 12 years who identified Ascaris lumbricoides worms and eggs in their feces, and this study has received ethical permission from the Health Research Ethics Commission (KEPK) Faculty of Medicine, University of North Sumatra.

\section{RESULTS}

From the research results obtained 63 research subjects, wherein table 1 can be seen in the distribution of subjects based on gender.

Table 2 involves the distribution of subjects based on the age of the patient. In table 3 we can see the distribution of subjects based on nutritional status. 
Table 4 shows the distribution of the subjects based on the patient's hemoglobin level, while in table 5 we can see the distribution of patients based on eosinophil levels.

Table 1. Distribution of Subjects by Gender

\begin{tabular}{|c|c|c|c|c|}
\hline \multirow{3}{*}{ Gender characteristics } & \multicolumn{2}{|c|}{ The results of stool examination using the Kato method } & \multirow[b]{2}{*}{ Total } & \multirow{3}{*}{$p$-value } \\
\hline & $\begin{array}{l}\text { Single infection } \\
\text { A. lumbricoides }\end{array}$ & $\begin{array}{l}\text { Mix infection and eggs } \\
\text { A. Iumbricoides (-) }\end{array}$ & & \\
\hline & n $(\%)$ & $\mathrm{n}(\%)$ & n $(\%)$ & \\
\hline Male & $7(11,1)$ & $26(41,3)$ & $33 \quad(52,4)$ & \\
\hline Female & $5(7,9)$ & $25(39,7)$ & $30 \quad(47,6)$ & 0,6463 \\
\hline Total & $12(19,0)$ & $51(81,0)$ & $63(100,0)$ & \\
\hline
\end{tabular}

Table 2. Distribution of Subjects by Age

\begin{tabular}{|c|c|c|c|c|}
\hline \multirow{3}{*}{ Characteristics } & \multicolumn{2}{|c|}{ The results of stool examination using the Kato method } & \multirow[b]{2}{*}{ Total } & \multirow{3}{*}{ p-value } \\
\hline & $\begin{array}{l}\text { Single infection } \\
\text { A. lumbricoides }\end{array}$ & $\begin{array}{l}\text { Mix infection and eggs } \\
\text { A. lumbricoides (-) }\end{array}$ & & \\
\hline & n $(\%)$ & $\mathrm{n}(\%)$ & n $(\%)$ & \\
\hline \multicolumn{5}{|l|}{ Age } \\
\hline Preschool age & $8(12,7)$ & $37(58,7)$ & $45 \quad(71,4)$ & \multirow{3}{*}{0,6848} \\
\hline School age & $4(6,3)$ & $14(22,3)$ & $18(28,6)$ & \\
\hline Total & $12(19,0)$ & $51(81,0)$ & $63(100,0)$ & \\
\hline
\end{tabular}

Table 3. Distribution of Subjects Based on Nutritional Status.

\begin{tabular}{|c|c|c|c|c|}
\hline \multirow{3}{*}{ Characteristics } & \multicolumn{2}{|c|}{$\begin{array}{l}\text { The results of stool examination using the } \\
\text { Kato method }\end{array}$} & \multirow[b]{2}{*}{ Total } & \multirow{3}{*}{$p$-value } \\
\hline & \multirow{2}{*}{$\begin{array}{c}\text { Single infection } \\
\text { A. lumbricoides } \\
\mathrm{n} \quad(\%)\end{array}$} & $\begin{array}{c}\text { Mix infection and } \\
\text { eggs } \\
\text { A. lumbricoides (-) }\end{array}$ & & \\
\hline & & n $(\%)$ & n $(\%)$ & \\
\hline \multicolumn{5}{|l|}{ Nutritional status } \\
\hline Poor nutritional status & $3(4,8)$ & $16(25,4)$ & $19 \quad(30,2)$ & \multirow{3}{*}{0,6651} \\
\hline Good nutritional status & $9(14,2)$ & $35(55,6)$ & $44 \quad(69,8)$ & \\
\hline Total & $12(19,0)$ & $51(81,0)$ & $63(100,0)$ & \\
\hline
\end{tabular}


Table 4. Distribution of Subjects Based on Hemoglobin Levels

\begin{tabular}{|c|c|c|c|c|}
\hline \multirow{3}{*}{ Characteristics } & \multicolumn{2}{|c|}{$\begin{array}{l}\text { The results of stool examination using the } \\
\text { Kato method }\end{array}$} & \multirow[b]{2}{*}{ Total } & \multirow{3}{*}{$p$-value } \\
\hline & $\begin{array}{l}\text { Single infection } \\
\text { A. lumbricoides }\end{array}$ & $\begin{array}{c}\text { Mix infection and } \\
\text { eggs } \\
\text { A. lumbricoides (-) }\end{array}$ & & \\
\hline & n $(\%)$ & $\mathrm{n}(\%)$ & n $\quad(\%)$ & \\
\hline \multicolumn{5}{|l|}{ Hemoglobin levels } \\
\hline Normal & $6(9,5)$ & $35(55,6)$ & $41 \quad(65,1)$ & \multirow{3}{*}{0,2232} \\
\hline Anemia & $6(9,5)$ & $16(25,4)$ & $22 \quad(34,9)$ & \\
\hline \multirow[t]{2}{*}{ Total } & $12(19,0)$ & $51(81,0)$ & $63(100,0)$ & \\
\hline \multirow{2}{*}{\multicolumn{4}{|c|}{$\begin{array}{c}\text { Table 5. Distribution of Subjects Based on Eosinophils Levels } \\
\text { The results of stool examination using the }\end{array}$}} & \\
\hline & $\begin{array}{r}\text { The results of sto } \\
\text { Kat }\end{array}$ & $\begin{array}{l}\text { amination using the } \\
\text { ethod }\end{array}$ & & \multirow{3}{*}{$p$-value } \\
\hline \multirow[t]{2}{*}{ Characteristics } & $\begin{array}{l}\text { Single infection } \\
\text { A. lumbricoides }\end{array}$ & $\begin{array}{c}\text { Mix infection and } \\
\text { eggs } \\
\text { A. lumbricoides (-) }\end{array}$ & Total & \\
\hline & $n \quad(\%)$ & $n \quad(\%)$ & $n \quad(\%)$ & \\
\hline \multicolumn{5}{|l|}{ Eosinophil levels } \\
\hline Normal & $9(14,3)$ & $49(77,8)$ & $58 \quad(92,1)$ & \multirow{3}{*}{0,0150} \\
\hline Eosinophilia & $3(4,7)$ & $2(3,2)$ & $5 \quad(7,9)$ & \\
\hline Total & $12(19,0)$ & $51(81,0)$ & $63(100,0)$ & \\
\hline
\end{tabular}

\section{DISCUSSION}

The number of research subjects found was 63 people, this is most likely due to being a hospital that facilitates the Social Security Administering Body (BPJSKesehatan) health program, Martha Friska Brayan Hospital can only serve referral patients who carry cover letters. This tiered referral system reduces the number of patient visits from areas with a high number of A. lumbricoides worm infections in North Sumatra to seek treatment at Martha Friska Brayan Hospital, the number of these subjects looks small when compared to a study conducted by Samosir in 2012 in Medan Municipality, the number of A. lumbricoides worms was $30.7 \%$ of all worms. ${ }^{4}$ The results of a UNICEF survey in 2003 showed that A. lumbricoides in North
Sumatra reached $50 \%$ to $79.9 \%$ of all worm infections. ${ }^{3,4}$ Another study that took research samples from other areas in North Sumatra showed that the number of $\mathrm{A}$. lumbricoides worms was almost the same. This can be seen from the results of Daulay's research in 2008 in Sibolga Regency which showed that the number of A. lumbricoides worms was $54.2 \%$ of all cases of worms. ${ }^{5}$ Simarmata's research in 2010 in Kaban Jahe District, Karo Regency was $41.3 \%$, and Juwita's research in 2013 in Serdang Bedagai Regency was 69.8\%. .,6,7 $^{\text {. }}$

The number of patients with a single infection with A. lumbricoides who were male was greater than the number of patients with female, namely 33 male patients $(23.3 \%)$ and 30 female patients (16.7\%). This difference is not significant. This is due 
to differences in lifestyles, behaviors, and habits of the gender differences between men and women which are not different in this age group so that the male and female groups have the same chance of being infected by A. lumbricoides worms.

Another study in North Sumatra did not separate A. lumbricoides worm infection with other soil-borne worm infections, as seen in the results of Simarmata's 2012 study. ${ }^{6}$ This study also showed that the number of people with worms transmitted through the soil who were male was $46.2 \%$ and less than that of women was $53.7 \%$. However, there was no association between gender with A. lumbricoides worm infection in this study. Likewise with the results of Samosir's research in 2013 (37.3\% vs 46.3\%). ${ }^{4,6}$

Juwita's research showed that there were more male sufferers than female patients $(80.5 \%$ vs $76.4 \%)$, but there was no association found between gender characteristics with A. lumbricoides worm infection in this study. ${ }^{7}$

The results of the research at Martha Friska Pulo Brayan Hospital showed that most ascariasis sufferers suffered at preschool age, namely $71.4 \%$, this can be related to the level of child development, where at pre-school age children are still at the intellectual maturation stage growth. Children have not been able to distinguish between right and wrong things for health, so they have a higher tendency to suffer from worms compared to school age. ${ }^{2}$ The findings in this study are also in line with a survey conducted by UNICEF in Indonesia showing that A. lumbricoides worms are higher in the pre-school age group $(63.7 \%$ at pre-school age and $53.0 \%$ at school age). ${ }^{3}$

The results of research at Martha Friska Pulo Brayan Hospital showed that $30.2 \%$ of patients with A. lumbricoides infection suffered from malnutrition. Nutritional disturbances in ascariasis are caused by impaired absorption of food by worms so that the body's cells do not receive optimal amounts of nutrition, but this condition usually occurs in chronic ascariasis. $^{7}$ The findings of nutritional disorders status in this study were not that big when compared to the number of patients with decreased nutritional status in Juwita's study, which amounted to $45.0 \%$, and in Simarmata's study, which amounted to $64.7 \%$ of the total cases of A. lumbricoides worm infection in the area they were living in thorough. 6,7

In this study, $34.9 \%$ of ascariasis subjects suffered from anemia, this is due to impaired function of food absorption due to infection in the body so that nutrients cannot be absorbed properly by the body, besides migration of worm eggs outside the digestive tract such as in the lungs. lungs that cause coughing symptoms in children, this can reduce appetite, plus the presence of gastrointestinal symptoms such as nausea and vomiting. 8,9

In this study, an increase in the number of eosinophils occurred in $7.9 \%$ of all ascariasis patients. Eosinophilia can be a marker of parasitic infection in the body, including ascariasis, but in a short time infection sometimes does not increase eosinophil levels in the body. ${ }^{10,11,12}$

\section{CONCLUSION}

Ascariasis at General Hospital Martha Friska Pulo Brayan Medan from January to October 2017, aged 2-12 years, totaling 63 people, most of whom are male, pre-school age with good nutritional status, have normal $\mathrm{Hb}$ and Eosinophil levels.

\section{REFERENCES}

1. de Silva N, Brooker S, Hotez P, Montresor A, Engels D, Savioli L. Soil- 
transmitted helminth infections: updating the global picture. Trends in Parasitology.2013;19(12): 547-551.

2. Siregar CD. Pengaruh infeksi cacing usus pada pertumbuhan fisik anak usia sekolah dasar. Sari Pediatri. 2006;8 (2):112-7.

3. United Nations Children's Fund, East Asia and Pacific Regional Office. Mapping human helminth infections in Southeast Asia. Bangkok. 2003. UNICEF East Asia \& Pacific Regional Office.

4. SamosirA. Hubungan antara derajat infeksi cacing yang ditularkan melalui tanah terhadap tingkat kecerdasan pada anak di SD negeri 067775 kotamadya Medan [Tesis]. Repository Universitas Sumatera Utara Program Studi Magister Ilmu Kedokteran Tropis.2013.

5. Daulay RRZ. Hubungan higiene perseorangan siswa dengan infeksi kecacingan anak SD negri di kecamatan Sibolga Kota Sibolga [Tesis]. Repository Universitas Sumatera Utara Sekolah Pasca Sarjana. 2008.

6. Simarmata N. Perbandingan Status Nutrisi antara Anak dengan dan tanpa Infeksi Soil Transmitted Helminths [Tesis]. Repository Universitas Sumatera Utara Program Studi Magister Kedokteran Klinik.2012.

7. Juwita E. Hubungan intensitas infeksi soil-transmitted helminths dengan status gizi dan nilai rapor pada anak: studi kasus SDN 102052 bagan kuala kabupaten Serdang Bedagai [Tesis]. Repository Universitas Sumatera Utara Program Studi Magister Ilmu Kedokteran Tropis. 2013.

8. Nutman TB. Evaluation and differential diagnosis of marked, persistent eosinophilia. Immunology and Allergy
Clinics of North America. 2007; 27(3): 529-549.

9. Deeks J. Diagnostic tests 4: likelihood ratios. BMJ. 2004; 329(7458): 168-169.

10. Grimes D, Schulz K. Refining clinical diagnosis with likelihood ratios. The Lancet. 2005; 365(9469): 1500-1505.

11. Nikolay B, Brooker S, Pullan R. Sensitivity of diagnostic tests for human soil-transmitted helminth infections: a meta-analysis in the absence of a true gold standard. International Journal for Parasitology. 2014; 44(11): 765-774.

12. Shin M, Lee Y, Min D. Eosinophilmediated tissue inflammatory responses in helminth infection. The Korean Journal of Parasitology. 2009; 47(Suppl): S125. 